\title{
PENGARUH PENGGUNAAN APLIKASI CHEMSKETCH DENGAN METODE RESITASI TERHADAP HASIL BELAJAR PADA MATERI HIDROKARBON
}

\section{The Effect of The Use Chemsketch Application Using Resitation Method on The Results of Learning in Hydrocarbon Materials}

\author{
Nuranisa*, Yudha Irhasyuarna, Rilia Iriani \\ Program Studi Pendidikan Kimia FKIP Universitas Lambung Mangkurat, \\ Jl. Brigjend. H. Hasan Basry Banjarmasin 70123 Kalimantan Selatan Indonesia \\ *email: nuranisakimia1995@gmail.com
}

\begin{abstract}
Abstrak. Telah dilakukan penelitian tentang pengaruh penggunaan aplikasi chemsketch dengan metode resitasi pada materi hidrokarbon untuk siswa kelas X SMA Negeri 1 Pulau Laut Selatan Kotabaru. Penelitian ini menggunakan empat kelas yaitu 3 kelas eksperimen dan 1 kelas kontrol. Penelitian ini bertujuan untuk mengetahui perbedaan hasil belajar pada kelas eksperimen 1 yang menerapkan pembelajaran yang menggunakan aplikasi chemsketch dengan metode resitasi pada kelas X4. Kelas eksperimen 2 mendapatkan pengajaran yang menerapkan metode resitasi pada kelas X1. Kelas eksperimen 3 yang mendapatkan pengajaran dengan menerapkan aplikasi chemsketch pada kelas X3 dan kelas kontrol menerapkan pembelajaran ekspositori pada kelas $\mathrm{X} 2$. Metode yang digunakan adalah quasi experimen dengan desain nonequivalent control group. Variabel bebasnya adalah aplikasi chemsketch dan metode resitasi, sedangkan variabel terikatnya adalah hasil belajar. Analisis data menggunakan teknik analisis deskriptif dan inferensial. Analisis deskriptif digunakan untuk mengetahui perbedaan hasil belajar ranah sikap dan keterampilan. Analisis inferensial menggunakan uji anava 1 jalur (one way anava) untuk menganalisis perbedaan eksperimen 1, 2, 3, dan kontrol terhadap hasil belajar. Pengumpulan data dalam penelitian ini menggunakan teknik tes dan nontes. Hasil rata-rata validitas yang didapatkan sebesar 0,99 yang berarti instrumen dikatakan valid dengan koefisien reliabilitas sebesar 0,79 termasuk dalam kategori sedang sehingga dapat dipercaya sebagai alat ukur dan layak digunakan untuk penelitian. Hasil penelitian menunjukkan adanya perbedaan yang signifikan terhadap hasil belajar pada eksperimen 1, 2, 3 dan Kontrol. Eksperimen yang paling berpengaruh terhadap hasil belajar dalam penelitian ini adalah eksperimen 1 yang menggunakan aplikasi chemsketch dengan metode resitasi kemudian disusul dengan eksperimen 3 yang menggunakan aplikasi chemsketch dan yang terakhir adalah eksperimen 2 yang menerapkan metode resitasi.
\end{abstract}

Kata kunci: aplikasi chemsketch, metode resitasi, hasil belajar, dan hidrokarbon

\begin{abstract}
Research has been conducted on the effect of using chemsketch application with recitation method on hydrocarbon material for class $X$ students of SMA Negeri 1 Pulau Laut Selatan Kotabaru. This study uses four classes, namely 3 experimental classes and 1 control class. This study aims to determine the differences in learning outcomes in the experimental class 1 that applies learning using the chemsketch application with the recitation method in class $X 4$. The experimental class 2 gets teaching that applies the recitation method to class X1. The experimental class 3 which received teaching by applying the chemsketch application in class X3 and the control class applied expository learning in class X2. The method used is quasi-experimental with nonequivalent control group design. The independent variable is the
\end{abstract}


chemsketch application and recitation method, while the dependent variable is learning outcomes. Data analysis uses descriptive and inferential analysis techniques. Descriptive analysis is used to determine differences in learning outcomes in the realm of attitudes and skills. Inferential analysis uses anava 1path test (one way anava) to analyze differences in experiments 1, 2, 3, and control of learning outcomes. Data collection in this study uses test and nontest techniques. The average result of validity obtained is 0.99 which means that the instrument is said to be valid with a reliability coefficient of 0.79 included in the medium category so that it can be trusted as a measuring tool and is suitable for research. The results showed a significant difference in learning outcomes in experiments 1, 2, 3 and Control. Experiments that have the most influence on learning outcomes in this study are experiment 1 which uses the chemsketch application with the recitation method then followed by experiment 3 which uses the chemsketch application and the last is experiment 2 which applies the recitation method.

Keywords: chemsketch application, recitation method, learning outcomes, and hydrocarbons

\section{PENDAHULUAN}

Ilmu kimia adalah salah satu ilmu pengetahuan yang mencakup berupa konsep dan fakta, teori yang didapatkan melalui analisis ilmiah yang cenderung bersifat abstrak. Guru dituntut untuk menguasai berbagai macam keterampilan dalam mengajarkannya di kelas (Fahmi \& Irhasyuarna, 2017). Keterampilan yang harus dimiliki oleh guru adalah mampu memberi informasi atau pengetahuan, mampu melatihkan keterampilan dan mampu membimbing peserta didik untuk lebih baik.

Ketika seorang guru melakukan pembelajaran, guru hendaknya membimbing dan memastikan informasi tentang materi pelajaran sampai kepada peserta didik yang akan berdampak pada keterampilannya dalam menyelesaikan masalah. Sardiman (2014) menyatakan bahwa guru sebagai pembimbing,pendidik dan pengajar, dibutuhkan adanya peranan dalam diri guru. Peranan guru sangat penting dalam pembelajaran yang dapat menggambarkan pola tingkah laku dari berbagai interaksinya terhadap peserta didik, sesama staf maupun guru-guru yang lainnya, dan diberbagai kegiatan interaksi pembelajaran.

Masih banyak peserta didik yang menganggap kimia sebagai pelajaran yang sangat rumit karena mengandung banyak istilah-istilah yang sulit dipahami. Hal ini dipengaruhi oleh penyampaian guru yang cenderung monoton sehingga menjadikan peserta didik cepat bosan saat proses pembelajaran berlangsung, yang berdampak pada kurangnya pemahaman peserta didik dan rendahnya prestasi belajar mereka dalam mata pelajaran kimia. Sejalan dengan hasil penelitian Ismail, Laliyo \& Alio (2013) yang menunjukkan bahwa penyebab menurunnya hasil belajar peserta didik disebabkan guru masih dominan menggunakan metode konvensional, yang mengakibatkan proses pembelajaran menjadi sangat membosankan. Sehingga berdampak pada pengetahuan dan pengalaman belajar terbatas.

Berdasarkan hasil penelitian Sitepu (2016) rata-rata nilai kimia kelas XI SMK sebesar 62.57 ( 16 dari 35 peserta didik ) nilai tertinggi yang dicapai sebesar 75 dan nilai yang terendah sebesar 45 dengan kriteria ketuntasan minimal sebesar 65, sehingga peserta didik hanya mencapai $45,71 \%$ yang dapat memenuhi kriteria ketuntasan minimal. Rendahnya hasil belajar peserta didik menunjukkan rendahnya penguasaan materi mereka. Hal ini terjadi karena akibat metode dan media yang digunakan kurang bervariasi dalam pembelajaran dalam mengajarkan materi kepada peserta didik. Agustina, Nugroho, \& Mulyani (2013) dalam hasil penelitiannya 
ditemukan fakta bahwa penyebab rendahnya hasil belajar peserta didik dikarenakan metode yang diterapkan pada proses belajar mengajar masih memakai metode ceramah.

Metode konvensional atau metode ceramah ini tidak menyita banyak waktu akan tetapi metode ini kurang efektif dalam menumbuhkan aktivitas peserta didik serta menyebabkan kebosanan, sehingga peserta didik sulit memahami materi, terutama pada penentuan tata nama senyawa yang kompleks dan penentuan atom karbon ujung. Materi hidrokarbon membutuhkan pemahaman konsep yang tidak bisa dipahami hanya dengan menghafal saja namun membutuhkan pemahaman konsep yang kuat (Perdana, Utomo \& Yamtinah, 2014).

Peserta didik membutuhkan alat bantu yang menarik dan juga mampu meningkatkan aktivitas dan motivasi belajar peserta didik untuk memahami pelajaran. Alat bantu yang dapat digunakan yaitu penggunaan media, penggunaan media interaktif dalam pembelajaran dapat menciptakan proses pembelajaran yang menarik, interaktif, menyenangkan dan efektif dan menjadi salah satu sebab berhasilnya proses belajar mengajar di dalam kelas (Akbar, Irhasyuarna \& Rusmansyah, 2015)

Media memiliki tiga fungsi utama sebagai media pengajaran, sebagai penyampai pesan dalam pengajaran, dan sebagai elemen sensorik. Ketiga fungsi ini, menambah perhatian peserta didik, minat dan keantusiasan padaproses pembelajaran ketika multimedia digunakan dan diintegrasikan dalam kegiatan belajar mengajar (Umar \& Aziz, 2015). Pada masa sekarang ini, media yang sangat menarik bagi peserta didik adalah media yang berbasis IT atau komputer. Penggunaan media komputer sebagai alat bantu belajar sangat menarik dan bermanfaat bagi peserta didik. Berbagai jenis software telah tersedia untuk mempermudah kita dalam menggunakan peralatan elektronik lain seperti laboratorium virtual. Selain itu, media elektronik lainnya seperti komputer juga dapat mengintegrasikan materi-materi kimia yang cenderung bersifat abstrak dan juga dapat menambah daya ingatan (long time memory), menambah minat, dan perhatian peserta didik sepanjang proses belajar mengajar berlangsung.

Diantara softwere yang menarik dan mudah digunakan adalah aplikasi chemsketch. Chemsketch adalah softwere kimia yang paling banyak dipakai oleh para peneliti di dunia untuk menggambarkan struktur sederhana maupun struktur kompleks (Li, Honggui, Ahmad, \& Pingkai, 2004). Chemsketch dapat mempermudah kita untuk memahami pembelajaran kimia terutama pada materi hidrokarbon dalam tata nama senyawa. Chemsketch dapat menampilkan struktur molekul dalam bentuk 3D untuk memudahkan peserta didik dalam membayangkan dan memahami bentuk suatu molekul kimia.

Aplikasi chemsketch dapat digunakan sebagai media pembelajaran yang berperan dalam membantu meningkatkan hasil belajar peserta didik. Aplikasi chemsketch membekali peserta didik untuk mengubah representasi molekul 2D menjadi 3D. Pengubahan representasi tersebut untuk mengasah keterampilan mereka menghubungkan struktur sehingga dapat membayangkan potensi interaksi dalam ruang 3D (Cody, Craig, Loudermilk, Yacci, Frisco \& Milillo, 2012). Situasi ini mengakibatkan pembelajaran menggunakan media ini menjadi lebih menarik dan membekas dalam ingatan peserta didik.

Penggunaan aplikasi chemsketch harus dikombinasikan dengan metode pengajaran yang cocok dengan karakteristik aplikasi dan juga materi pelajaran. Penggunaan suatu metode pembelajaran yang cocok harus ditinjau dari segi karakteristik materi pelajaran serta keadaan peserta didik. Karakteristik yang dimaksud adalah, potensi, waktu yang dimiliki, minat, keadaan sosial ekonomi siswa sebagai obyek dan kecepatan belajar (Wibowo, 2014). 
Metode pembelajaran yang cocok digunakan dengan media chemsketch adalah metode resitasi. Penggunaan metode resitasi dalam pembelajaran ini yang menggunakan chemsketch menekankan pada penugasan dalam penguasaan materi untuk menghubungkan proses berfikir peseta didik kearah pengembangan intelektualnya. Penggunaan aplikasi chemsketch diyakini lebih efisien dan efektif dalam pembelajaran. Sitepu (2016) dalam hasil penelitiannya mengungkapkan bahwa adanya interaksi antara penggunaan media chemsketch dan metode resitasi dengan motivasi belajar sehingga dapat meningkatkan hasil belajar peserta didik.

Riset yang telah dilakukan sebelumnya membuktikan bahwa teori tersebut sejalan dengan bukti empirik dalam kehidupan, seperti penelitian Sitepu (2016) menemukan fakta bahwa penggunaan chemsketch dengan menggunakan metode resitasi memperoleh hasil signifikan terhadap hasil belajar. Li, Honggui, Ahmad, \& Pingkai (2004) dan Cody, Craig, Loudermilk, Yacci, Frisco \& Milillo, (2012) menemukan fakta bahwa chemsketch dapat mengasah keterampilan dan mempermudah kita dalam menggambarkan suatu bentuk molekul yang kompleks dalam bentuk 3D. Utami, Sulfikar, \& Anwar (2017) juga menemukan fakta bahwa aplikasi chemsketch dengan metode resitasi dalam pembelajaran kimia berpengaruh positif pada hasil belajar.

Pada uraian diatas, penting dilakukan penelitian tentang penerapan metode resitasi dan penggunaan aplikasi chemsketch dalam pembelajaran kimia terhadap hasil belajar pada materi hidrokarbon. Diharapkan proses belajar mengajar akan lebih efektif dan menyenangkan untuk membantu peserta didik dalam memahami pelajaran khususnya pada materi hidrokarbon.

\section{METODE PENELITIAN}

Penelitian ini menggunakan metode eksperimen semu (quasy experiment). Rancangan dalam penelitian ini melibatkan 4 kelas yaitu 3 kelas sebagai kelas eksperimen dan 1 kelas sebagai kelas kontrol. Dampak dari suatu perlakuan pada desain ini akan diuji dan dianalisis dengan membandingkan variabel terikat pada kelas kontrol yang tidak diberi perlakuan dengan kelas eksperimen yang telah diberi perlakuan.

Pada kelas eksperimen maupun kelas kontrol diberi pre-test sebelum diberikan pembelajaran dan post-test setelah diberikan pembelajaran yang menggunakan aplikasi chemsketch dengan metode resitasi pada akhir penelitian. Penelitian ini menggunakan desain quasy experimental design dapat dilihat pada Tabel 1.

Tabel 1. Desain penelitian nonequivalent control group design

\begin{tabular}{ccc}
\hline Pengukuran (Pre-test) & Perlakuan & Pengukuran (Post-test $)$ \\
\hline Y & $\mathrm{X}_{1}$ & $\mathrm{Z}_{1}$ \\
$\mathrm{Y}$ & $\mathrm{X}_{2}$ & $\mathrm{Z}_{2}$ \\
$\mathrm{Y}$ & $\mathrm{X}_{3}$ & $\mathrm{Z}_{3}$ \\
$\mathrm{Y}$ & $\mathrm{X}_{4}$ & $\mathrm{Z}_{4}$ \\
\hline & & Sumber : Sugiyono (2016)
\end{tabular}

Keterangan :

$\mathrm{Y}=$ Pre-test sebelum diberikan perlakuan

$\mathrm{X}_{1}=$ Perlakuan menggunakan aplikasi chemsketch dan metode resitasi

$\mathrm{X}_{2}=$ Perlakuan menerapkan metode resitasi

$\mathrm{X}_{3}=$ Perlakuan menggunakan aplikasi chemsketch

$\mathrm{X}_{4}=$ Perlakuan menerapkan metode ekspositori

$\mathrm{Z}_{1}=$ Post-tes menggunakan apliaksi chemsketch dan metode resitasi 
$\mathrm{Z}_{2}=$ Post-tes menerapkan metode resitasi

$\mathrm{Z}_{3}=$ Post-tes menggunakan aplikasi chemsketch

$\mathrm{Z}_{4}=$ Post-tes menerapkan metode ekspositori

Eksperimen 1 yang mendapatkan pembelajaran dengan menggunakan aplikasi chemsketch dengan metode resitasi sebanyak 30 peserta didik pada kelas X4. Eksperimen 2 yang mendapatkan pembelajaran dengan metode resitasi sebanyak 30 peserta didik pada kelas X1. Eksperimen 3 yang mendapatkan pembelajaran dengan menggunakan aplikasi chemsketch sebanyak 30 peserta didik pada kelas X3. Kelas kontrol menerapkan pembelajaran ekspositori sebanyak 30 peserta didik pada kelas $\mathrm{X} 2$.

Populasi dalam penelitian ini adalah seluruh peserta didik kelas X SMA Negeri 1 Pulau Laut Selatan Kotabaru tahun ajaran 2017/2018 yang terdiri dari 4 kelas dan total jumlah siswanya sebanyak 120 siswa. Teknik pengambilan sampel yang digunakan adalah purposive sampling. Purposive sampling adalah teknik penentuan sampel dengan tujuan atau pertimbangan tertentu (Arikunto, 2016). Sampel dalam penelitian ini adalah Kelas X di SMA Negeri 1 Pulau Laut Selatan Kotabaru, berjumlah 4 kelas yakni kelas X1, X3, X4 sebagai kelas eksperimen dan X2 sebagai kelas kontrol.

\section{HASIL PENELITIAN DAN PEMBAHASAN}

Telah dilakukan penelitian dan diperoleh data hasil belajar kognitif dan afektif peserta didik antara kelas kontrol yang diterapkan pembelajaran ekspositori dan kelas eksperimen yang menggunakan aplikasi chemsketch dengan metode resitasi. Data hasil belajar kognitif peserta didik yang didapatkan melalui tes awal atau pre-tes dan tes akhir atau post-tes akan dianalisis secara deskriptif dan inferensial, sedangkan data hasil belajar afektif peserta didik yang diperoleh melalui observasi akan dianalisis secara deskriptif.

Hasil belajar kognitif pada eksperimen 1 menunjukkan bahwa nilai terendah yang diperoleh peserta didik adalah 5 dan nilai tertinggi 100. Pada eksperimen 2 hasil belajar peserta didik memperoleh nilai terendah 0 dan nilai tertinggi yang diperoleh adalah 90. Kelas eksperimen 3 hasil belajar peserta didik memperoleh nilai terendah 5 dan nilai tertinggi yang diperoleh adalah 95 dan nilai terendah yang diperoleh pada kelas kontrol (ekspositori) adalah 0 dan nilai tertinggi yang dicapai adalah 85 hal ini dapat dilihat pada Tabel 1.

Tabel 1. Data hasil pre-tes dan post-tes

\begin{tabular}{ccccc}
\hline Kelas & $\begin{array}{c}\text { Nilai } \\
\text { terendah } \\
\text { Pre-test }\end{array}$ & $\begin{array}{c}\text { Nilai } \\
\text { tertinggi } \\
\text { Post-test }\end{array}$ & $\begin{array}{c}\text { Jumlah } \\
\text { sampel }\end{array}$ & Ketuntasan \\
\hline Eksperimen 1 & 5 & 100 & 30 & 27 \\
Eksperimen 2 & 0 & 90 & 30 & 25 \\
Eksperimen 3 & 5 & 95 & 30 & 26 \\
Kontrol & 0 & 85 & 30 & 17 \\
\hline
\end{tabular}

Berdasarkan Tabel 1 diatas terlihat bahwa dari segi aspek hasil belajar kognitif baik pada kelas kontrol maupun kelas eksperimen sebelum pembelajaran didapatkanhasil belajar rata-rata rendah. Hal ini dikarenakan peserta didik belum mengenal dan memahami materi hidrokarbon Setelah dilakukan pembelajaran didapatkan hasil belajar kognitif peserta didik kelas kontrol relatif lebih rendah di bandingkan dengan kelas eksperimen. ketuntasan hasil belajar peserta didik pada eksperimen 1 lebih tinggi di bandingkan dengan kelas yang lain yaitu sebesar 27 
peserta didik yang tuntas, hal ini dikarenakan pada eksperimen 1 menggunakan aplikasi chemsketch dengan metode resitasi yang menkankan aktivitas peserta didik untuk menemukan konsep sendiri dan secara langsung menggunakan aplikasi chemsketch sehingga peserta didik dapat mengkonstruksikan pengetahuannya secara nyata. Kemudian disusul dengan kelas eksperimen 3 ketuntasan peserta didik sebanyak 26 lebih rendah dari kelas eksperimen 1 hal ini dikarenakan eskperimen 3 hanya menggunakan aplikasi chemsketch dan sebagian peserta didik belum mahir menggunakan aplikasi tersebut sehingga masih terkendala dalam penggunaan aplikasi akan tetapi peserta didik sudah bisa memahami bentuk molekul secara nyata. Kelas eksperimen 2 ketuntasan peserta didik lebih rendah dari eksperimen 1 dan 3 yaitu sebanyak 25. Hal ini dikarenakan eskperimen 2 hanya menerapkan metode resitasi. Peserta didik tidak terlibat langsung dalam penggambaran molekul hanya saja peserta didik mencari literatur bahan ajar dari berbagai sumber sehingga masih ada peserta didik yang belum bisa memahami bentuk molekul secara nyata sedangkan pada kelas kontrol ketuntasan peserta didik sebanyak 17 hampir dari setengah peserta didik pada kelas kontrol hal ini disebabkan peserta didik hanya mendengarkan penjelasan guru (teacher center) dan masih bergantung menerimaan informasi hanya dari penjelasan guru dan belum terbiasa belajar secara mandiri.

Secara keseluruhan peserta didik pada eksperimen mendapatkan nilai ratarata yang relatif lebih tinggi di bandingkan dengan kelas kontrol. Selain itu jumlah peserta didik yang mencapai ketuntasan belajar pada kelas eksperime 1, 2, dan 3 lebih besar dibandingkan dengan kelas kontrol, sehingga bisa dikatakan bahwa kelas eksperimen 1, 2, dan 3 mencapai ketuntasan hasil belajar yang lebih baik di bandingkan dengan kelas kontrol.

Selain ketuntasan hasil belajar, ketuntasan juga dapat dilihat pada tingkat pemahaman peserta didik terhadap materi hidrokarbon yang dihitung berdasarkan persentase jawaban tiap indikator pada post-tes untuk kelas kontrol dan kelas eksperimen 1, 2, dan 3 setelah proses pembelajaran dapat dilihat pada Gambar 1.

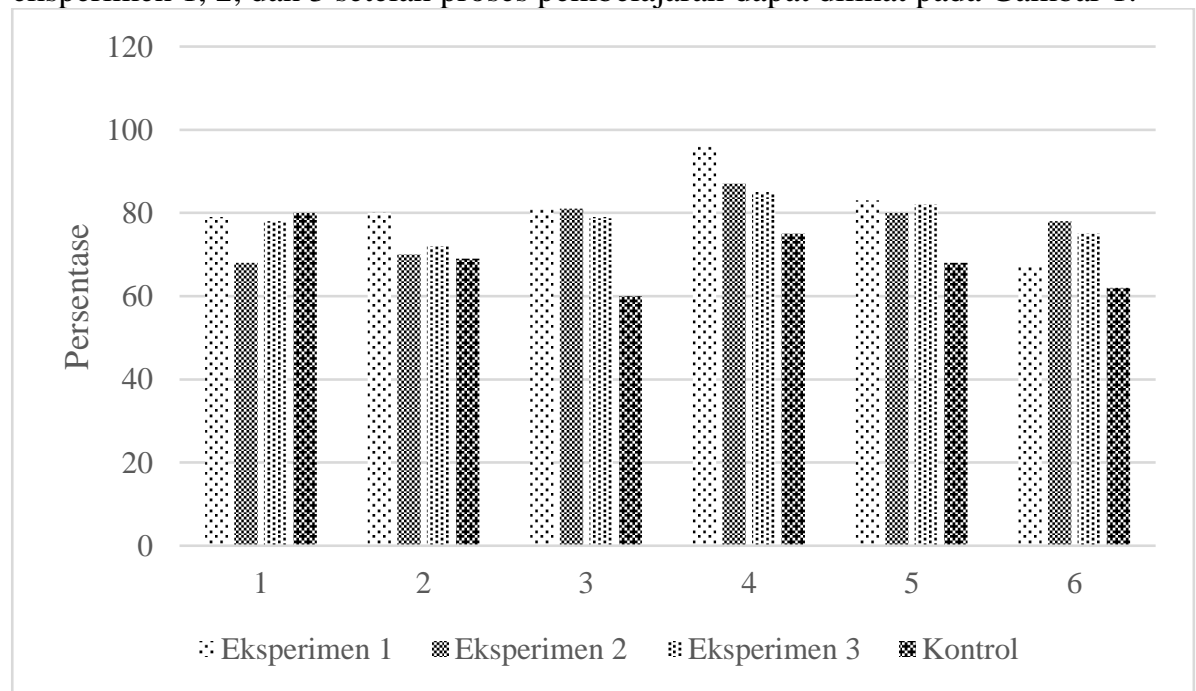

Gambar 1. Perbandingan tingkat pemahaman peserta didik

Berdasarkan Gambar 1 dapat dilihat bahwa dari 6 indikator secara keseluruhan pemahaman peserta didik pada eksperimen 1 relatif lebih tinggi dibandingkan dengan eksperimen 2, 3 dan kontrol indikator tersebut membahas tentang menggolongkan senyawa hidrokarbon berdasarkan kejenuhan ikatannya, 
menentukan rumus struktur senyawa hidrokarbon, memberi namasenyawa alkana,alkena, dan alkuna, menentukan jumlah isomer senyawa hidrokarbon, menentukan isomer struktur ( kerangka dan posisi ) dan isomer geometri ( cis dan trans ) senyawa hidrokarbon dan menganalisis isomer senyawa hidrokarbon. Hal ini telah membuktikan bahwa aplikasi chemsketch dengan metode resitasi berpengaruh positif terhadap hasil belajar peserta didik karena penggunaan aplikasi chemsketch dapat mempermudah kita dalam menggambarkan struktur sederhana maupun kompleks dan juga pada penerapan metode resitasi membuat peserta didik antusisas mencari informasi atau sumber belajar sehingga peserta didik dapat belajar secara mandiri ataupun berdiskusi dengan tutor sebaya dan dapat menambah wawasan peserta didik.

Berdasarkan pada analisis data terhadap pengujian normalitas hasil belajar pre-tes dan post-test untuk kelas eksperimen dan kelas kontrol dengan menggunakan uji normalitas liliefors. Secara singkat hasil perhitungan uji normalitas pre-test dan post-test dapat dilihat pada Tabel 2.

Tabel 2. Hasil uji normalitas pre-test dan post-tes

\begin{tabular}{ccccccc}
\hline \multirow{2}{*}{ Kelas } & \multicolumn{2}{c}{ Uji normalitas pre-test } & \multicolumn{3}{c}{ Uji normalitas post-test } \\
\cline { 2 - 7 } & Lhitung & $\mathbf{L}_{\text {tabel }}$ & Ket & Lhitung $^{\text {L }}$ & Ltabel & Ket \\
\hline Eksperimen 1 & 0,156 & 0,161 & Normal & 0,157 & 0,161 & Normal \\
Eksperimen 2 & 0,088 & 0,161 & Normal & 0,138 & 0,161 & Normal \\
Eksperimen 3 & 0,159 & 0,161 & Normal & 0,157 & 0,161 & Normal \\
Kontrol & 0,120 & 0,161 & Normal & 0,135 & 0,161 & Normal \\
\hline
\end{tabular}

Berdasarkan Tabel 2 menunjukkan sebaran data nilai pre -test dan nilai postest peserta didik keempat kelas berdistribusi normal sehingga dapat dilanjutkan dengan perhitungan uji homogenitas untuk mengetahui apakah sampel yang digunakan berasal dari populasi homogen. Hasil perhitungan uji homogenitas menggunakan uji Levene dapat dilihat pada Tabel 3.

Tabel 3. Hasil uji homogenitas Levene

\begin{tabular}{cccc} 
Levene statistic & df1 & df2 & Sig. \\
1.701 & 3 & 166 & .171 \\
\hline
\end{tabular}

Berdasarkan hasil perhitungan uji homogenitas dengan menggunakan SPSS 21 diperoleh hasil nilai $0.171>0.05$, maka dapat diinterpretasikan bahwa data memiliki varians homogen (sama). Perhitungan uji normalitas dan homogenitas di ketahui bahwa data terdistribusi normal dan memiliki varian yang homogen sehingga dapat dilanjutkan uji hipotesis dengan anava satu jalur (One Way Anava). Hasil perhitungan uji anava 1 jalur (one way anova) dapat dilihat pada Tabel 4.

Tabel 4. Hasil uji anava 1 jalur (one way anova)

\begin{tabular}{ccccccc} 
Sumber & $\begin{array}{c}\text { Jumlah } \\
\text { kuadrat }\end{array}$ & $\begin{array}{c}\text { Derajat } \\
\text { kebebasan }\end{array}$ & $\begin{array}{c}\text { Rataan } \\
\text { kuadrat }\end{array}$ & $\begin{array}{c}\text { F } \\
\text { hitung }\end{array}$ & $\begin{array}{c}\text { F } \\
\text { tabel }\end{array}$ & Interpretasi \\
$\begin{array}{c}\text { Antar } \\
\text { kelompok }\end{array}$ & 0,28 & 3 & 0,093 & & & \\
$\begin{array}{c}\text { Dalam } \\
\text { kelompok }\end{array}$ & 2,36 & 116 & 0,020 & 4,65 & 2,76 & Signifikan \\
Total & 2,64 & 119 & - & & & \\
\hline
\end{tabular}


Perhitungan anava 1 jalur diperoleh $\mathrm{F}_{\text {hitung }}$ sebesar 4,65 dengan $\alpha=5 \%, \mathrm{db}=$ 3 (pembilang) dan $\mathrm{db}=116$ (penyebut) diperoleh $\mathrm{F}_{\text {tabel }}$ sebesar 2,76. Hal ini menunjukkan $\mathrm{F}_{\text {hitung }}>\mathrm{F}_{\text {tabel }}$ maka $\mathrm{H}_{0}$ ditolak, Hal ini menunjukkan bahwa adanya perbedaan hasil belajar yang signifikan antara kelas eksperimen 1 yang menggunakan aplikasi chemsketch dengan metode reitasi,kelas eksperimen 2 yang menerapkan metode resitasi, kelas eksperimen 3 yang menggunakan aplikasi chemsketch serta kelas kontrol dengan pembelajaran ekspositori, untuk mengetahui eksperimen yang lebih berpengaruh terhadap hasil belajar dapat dilihat dari nilai rata-rata uji anava 1 jalur (one way anova).

Tabel 5. Rata-rata uji anava 1 jalur (one way anova)

\begin{tabular}{cc}
\hline Kelas & Rata-rata uji anava 1 jalur (one way anova) \\
\hline Eksperimen 1 & 21,77 \\
Eksperimen 2 & 20,19 \\
Eksperimen 3 & 20,87 \\
Kontrol & 17,80 \\
\hline
\end{tabular}

Berdasarkan rata-rata nilai uji anava 1 jalur terlihat bahwa kelas eksperimen 1 nemiliki nilai rata-rata yang lebih tinggi di bandingkan dengan kelas yang lain. Kelas eksperimen 1 mengalami peningkatan hasil belajar yang lebih besar dibandingkan dengan kelas yang lain setelah mendapatkan pembelajaran materi hidrokarbon dengan menggunakan aplikasi chemsketch dengan metode resitasi. Sehingga dapat dikatakan bahwa kelas eksperimen 1 yang menggunakan aplikasi chemsketch dengan metode resitasi yang paling efektif untuk meningkatkan hasil belajar peserta didik dengan nilai rata-rata 21,77, kelas eksperimen 2 yang menggunakan metode resitasi dengan nilai rata-rata 20,19 dan kelas eksperimen 3 yang menggunakan aplikasi chemsketch dengan nilai rata-rata 20,87 dan kelas kontrol yang menerapkan pembelajaran ekspositori dengan nilai rata-rata 17,80. Berdasarkan hasil perhitungan menunjukkan bahwa aplikasi chemsketch lebih memberikan pengaruh yang efektif di bandingkan dengan metode resitasi.

Adanya perbedaan yang signifikan tersebut menunjukkan bahwa penggunaan aplikasi chemsketch dengan metode resitasi berpengaruh signifikan pada hasil belajar kognitif peserta didik pada materi hidrokarbon. Pembelajaran yang menggunakan aplikasi chemsketch dengan metode resitasi menekankan pada aktivitas dan keterlibatan peserta didik dalam proses pembelajaran. Selain itu, pembelajaran yang menggunakan aplikasi chemsketch dengan metode resitasi menempatkan peserta didik sebagai subyek pembelajar sehingga guru hanya berperan sebagai motivator, fasilitator, dan pembimbing. Peserta didik terlibat langsung dalam menemuan konsep dan pengkonstruksian pengetahuannya akan dapat memproses informasi yang diterima berupa gambar seperti bentuk molekul sehingga peserta didik akan lebih mudah mengingat dan membekas dalam ingatan peserta didik (long time memory). Hal ini sejalan dengan penelitian yang telah dilakukan oleh Sitepu (2016) mengemukakan bahwa terdapat perbedaan yang signifikan terhadap hasil belajar antara pembelajaran yang menggunakan aplikasi chemsketch dengan metode resitasi dan pembelajaran konvensional (ekspositori).

Peneliti berupaya membuat suasana belajar yang aktif dan menyenangkan dengan menggunakan aplikasi chemsketch di sertai dengan metode resitasi. Berdasarkan pengamatan pada saat penelitian. kelas eksperimen 1 yang diajarkan menggunakan aplikasi chemsketch dengan metode resitasi, keantusiasan belajar peserta didik dalam proses pembelajaran lebih tinggi dibandingkan kelas yang lain dalam aspek rasa ingin tahu, tanggungjawab, disiplin dan berkomunikasi. Hal ini terlihat pada keantusiasan peserta didik ingin mencoba menggunakan aplikasi 
tersebut. Peserta didik juga aktif dan antusias dalam bertanya, berpendapat dan mencari informasi terlihat pada saat peserta didik mengerjakan tugas yang ada di LKS dengan menggunakan aplikasi chemsketch, peserta didik sangat aktif bertanya ketika mereka menemukan hal-hal baru yang belum diketahui seperti kegunaan ikon-ikon yang terdapat pada aplikasi chemsketch. Menurut Miftahuljannah (2016) mengatakan bahwa seringnya peserta didik menemukan konsep belajar sendiri akan membuat mandiri dan mudah mengingat kembali pembelajaran yang telah didapatkan sehingga peserta didik akan lebih aktif belajar dan memiliki pengalaman yang lebih banyak dalam mempelajari sesuatu dan pengetahuan peserta didik akan semakin bertambah dan mendalam.

Selain itu juga di sebabkan pada proses pembelajaran menggunakan aplikasi chemsketch adalah aplikasi pembelajaran yang baru di gunakan dalam proses belajar mengajar pada materi hidrokarbon untuk peserta didik di SMA Negeri 1 Pulau Laut Selatan Kotabaru. Sifat alami pada peserta didik sekolah menengah atas adalah selalu ingin mencoba sesuatu hal baru sehingga pada penggunaan media berbasis teknologi seperti aplikasi chemsketch yang dianggap baru bagi peserta didik. Selain itu penggunaan aplikasi atau media berbasis teknologi akan menarik dan menambah minat peserta didik dalam mempelajari dan memahami materi pelajaran yang akan diajarkan sehingga minat dan perhatian peserta didik yang tinggi dalam memahami suatu pelajaran terutama pada materi hidrokarbon akan meningkatkan hasil belajar peserta didik. Sejalan dengan penelitian yang dilakukan oleh Sitepu (2016) menyatakan bahwa adanya perbedaan yang signifikan terhadap hasil belajar antara pembelajaran yang menggunakan aplikasi chemsketch dengan metode resitasi dan pembelajaran konvensional (ekspositori).

\section{SIMPULAN}

Kesimpulan dalam penelitian ini yaitu terdapat perbedaan hasil belajar peserta didik yang signifikan antara kelas yang menggunakan aplikasi chemsketch dengan metode resitasi pada eksperimen 1, metode resitasi pada eksperimen 2, penggunaan aplikasi chemsketch pada eksperimen 3, dan kelas kontrol dengan pembelajaran ekspositori pada materi hidrokarbon. Eksperimen yang paling berpengaruh terhadap hasil belajar adalah eksperimen 1 yang menggunakan aplikasi chemsketch dengan metode resitasi kemudian disusul dengan eksperimen 3 yang menggunakan aplikasi chemsketch dan yang terakhir adalah eksperimen 2 yang menerapkan metode resitasi.

\section{DAFTAR RUJUKAN}

Agustina, E., C.S, A. N., \& Mulyani, S. (2013). Penggunaan Metode Pembelajaran JIGSAW Berbantuan Handout untuk Meningkatkan Hasil Belajar Siswa Pada Materi Hidrokarbon Kelas XC SMA Negeri 1 Gubug Tahun Ajaran 2012/2013. Jurnal Pendidikan KImia, 66-71.

Akbar, M., Irhasyuarna, Y., \& Rusmansyah. (2015). Pengembangan Media Pembelajaran Multimedia Interaktif Pada Materi Sistem Koloid. Quantum, Jurnal Inovasi Pendidikan Sains, 65-77.

Arikunto, S. (2016). Metode Penelitian Pendidikan. Bandung: Alfabeta.

Cody, J. A., Craig, P. A., Loudermilk, A. D., Yacci, P. M., Frisco, S. L., \& Milillo, J. R. (2012). Design and Implementation of a Self-Directed Stereo chemistry Lesson Using Embedded Virtual Three-Dimensional Images in a Portable Document Format. Journal of Chemical Education, 29-33.

Emzir. (2017). Metodelogi Penelitian Pendidikan. Depok: PT. Raja grafindo persada.

Fahmi, \& Irhasyuarna, Y. (2017). Misconception of Banjarmasin State High School Students in Chemical Commitment Materials. Journal of Research \& Method 
in Education, 54-61.

Ismail, M., Laliyo, L. A., \& Alio, L. (2013). Meningkatkan Hasil Belajar Ikatan Kimia dengan Menerapkan Strategi Pembelajaran Peta Konsep Pada Siswa Kelas X di SMA Negeri I Telaga. Jurnal Entropi, 1-10.

Li, Z., Wan, H., Shi, Y., \& Ouyang, P. (2004). Personal Experience with Four Kinds of Chemical Structure Drawing Software: Review on ChemDraw, ChemWindow, ISIS/Draw, and Chemsketch. Journal Chemistry Information Computation Science, 1886-1890.

Perdana, D. D., Utomo, S. B., \& Yamtinah, S. (2014). Upaya Peningkatan Minat dan Prestasi Belajar Materi Hidrokarbon Melalui Penerapan Model Pembelajaran Kooperatif Tipe Student Team Achievement Division (STAD) Berbantuan Kartu Soal Pada Siswa Kelas X Semester Genap SMA N 8 Surakarta Tahun Pelajaran 2012/2013. Jurnal Pendidikan Kimia, 74-79.

Sardiman, A. M. (2014). Interaksi \& Motivasi Belajar Mengajar. Jakarta: Rajagrafindo Persada.

Sitepu, C. P. (2016). Pengaruh Pemanfaatan Media Chemsketch dalam Pembelajaran yang Menggunakan Metode Resitasi Terhadap Motivasi dan Hasil Belajar Kimia di SMK Kelas XI. Jurnal Ilmiah, 1-19.

Sugiyono. (2016). Metode Penelitian Pendidikan Pendekatan Kuantitatif, Kualitatif, R \& D. Bandung: Alfabeta.

Umar, I. N., \& Aziz, Z. A. (2015). The effects of multimedia with different modes of presentation on recitation skills among students with different self-regulated learning level. Journal Procedia Social and Behavioral Sciences, 1962-1968.

Utami, H. H., Sulfikar, \& Anwar, M. (2017). Pengaruh Chemsketch dalam Penulisan Struktur Kimia Pada Metode Resitasi Terhadap Hasil Belajar Siswa (Materi Pokok Ikatan Kimia). Jurnal Penelitian Pendidikan INSANI, 96-100.

Wibowo, D. A., \& Hermawan, Y. (2014). Penerapan Metode Resitasi dan Diskusi untuk Meningkatkan Prestasi Belajar Mahasiswa Program Studi Ilmu Keperawatan Universitas Galuh. Jurnal Pendidikan dan Kebudayaan, 1-12. 